\title{
Research of Power Wireless Private Network Technology in the Terminal Communication Access Network
}

\author{
Feng Wang ${ }^{1}$, Yixin Ding ${ }^{2}$, Ming $\mathrm{Li}^{3}$, Junwei $\mathrm{Ma}^{1, *}$, Xincong Shi ${ }^{4}$ and Lei Yan ${ }^{5}$ \\ ${ }^{1}$ Information and Telecommunication Company of State Grid Shanxi Electric Power Corporation, No.169 Fudong Road, \\ 030001Taiyuan, China \\ ${ }^{2}$ Information and Telecommunication Company of State Grid Jiangsu Electric Power Corporation, No.215 Shanghai Road, \\ 210029Nanjing, China \\ ${ }^{3}$ Information and Telecommunication Company of State Grid Anhui Electric Power Corporation, No.9 Huangshan Road, \\ 230009Hefei, China \\ ${ }^{4}$ Jincheng Power Supply Company of State Grid Shanxi Electric Power Corporation, No.120 Xinshidong Road, \\ 0480001Jincheng, China \\ ${ }^{5}$ Power Control Center of State Grid Shanxi Electric Power Corporation, No.169 Fudong Road, \\ 030001Taiyuan, China \\ ${ }^{*}$ Corresponding author
}

\begin{abstract}
The terminal communication access network is an important part of the power communication network and is the extension of the backbone network, which will provide a comprehensive communication support for the smart grid construction. Firstly, in this paper, technical characteristics of TD-LTE power wireless private network is described. Secondly, comparison of the wireless technologies, such as TD-LTE, McWill, GPRS and CDMA, is analyzed in detail. Lastly, Construction scheme of the power wireless private network system is given in Shanxi province.
\end{abstract}

Keywords-wireless private network; TD-LTE; real time; transmission rate; base station

\section{INTRODUCTION}

State Grid Corporation proposed for the first time in the 12th five-year plan report: the power communication network is composed of the backbone network and the terminal communication access network (hereinafter referred to as access network). The access network is an important part of the power communication network and is the extension of the backbone network, which will provide a comprehensive communication support for the smart grid construction[1].

\section{TECHNICAL CHARACTERISTICS OF TD-LTE POWER WIRELESS PRIVATE NETWORK}

In the private network construction, MIIT(Ministry of Industry and Information Technology of the People's Republic of China) issued successively the file 59(2015) and 65(2015) and approved radio frequency of TD-LTE private network in power industry. The broadband TD-LTE smart city network has been built in Beijing and Nanjing. Moreover, TD-LTE power private network has also been built in Zhuhai and Guangzhou city. Therefore, safety and reliability are fully verified in these construction. Specific advantages are as follows:

\section{A. Safety Advantage}

Specific safety reinforcement will be used in the core network, base station and other power nodes from characteristics of electric power industry, which can improve the wireless communication security. In addition, there is no security risk with access to the Internet in the power private network.

\section{B. Construction Environment}

According to the present condition of Shanxi Power Company, fiber laying is all used in the power substation of $35 \mathrm{kV}$ and above. In other words, the new base station is full use of existing channels. Moreover, there is communication computer-room in the power station, which has natural advantage for building wireless base station.

\section{National Policy}

The file 65(2015) of MIIT clearly pointed out that TD-LTE $1785-1805 \mathrm{MHz}$ private wireless mode can be used in the power or oil industry. Therefore, in order to seize the initiative and output better smart grid standards, the power industry needs to speed up frequency resource application.

\section{Project Standard}

In 2013, Chongqing power company finished the application and approval of TD-LTE 1.8GHz and EMC(Electro Magnetic Compatibility) analysis work. TD-LTE $1.8 \mathrm{GHz}$ private system is built later for transformer monitoring and emergency communication information transmission. 
In 2015, TD-LTE $1.8 \mathrm{GHz}$ power private system is built in Nantong city of Jiangsu province for distribution automation, transformer monitoring and distributed power control information transmission.

Until now, TD-LTE $1.8 \mathrm{GHz}$ private wireless network has been built in Huaian, NanJing, Tangshan, Caofeidian, Fuzhou and Changsha by State Grid Corporation, which all Achieved good demonstration effect[2].

\section{E. Cost Advantage}

The private network adopts the similar technical system to the public. Compared to the fiber communication, the investment cost is lower and the construction speed is faster.

\section{COMPARISON OF THE DIFFERENT WIRELESS TECHNOLOGIES}

In the following chapters, A comprehensive comparison of TD-LTE, McWiLL, GPRS and CDMA is showed from the real time, reliability, security, rate and covering capacity[3].

\section{A. Real Time}

Owing to the limitation of technical system, public network load and terminal distribution etc., the real time of GPRS and CDMA is generally $0.6 s-2 s$. Moreover, network optimization management is out of power company's control. On the other hand, the transmission delay of wireless private network is much lower than of public network, so the real time performance is better. At present, the real time of TD-LTE1800 and McWiLL in the pilot power construction projects is about $300 \mathrm{~ms}$.

\section{TABLE I. COMPARISON OF REAL TIME FOR THE DIFFERENT WIRELESS TECHNOLOGIES}

\begin{tabular}{|c|c|c|c|c|c|}
\hline $\begin{array}{c}\text { Wireless } \\
\text { technology }\end{array}$ & $\begin{array}{c}\text { TD-LTE } \\
230\end{array}$ & $\begin{array}{c}\text { TD-LTE } \\
1800\end{array}$ & McWill & GPRS & $\begin{array}{c}\text { CD } \\
\text { MA }\end{array}$ \\
\hline Real time & $30-300 \mathrm{~ms}$ & $30-100 \mathrm{~ms}$ & $150-300 \mathrm{~ms}$ & $0.6-2 \mathrm{~s}$ & $\begin{array}{c}0.6- \\
2 \mathrm{~s}\end{array}$ \\
\hline
\end{tabular}

\section{B. Reliability}

The reliability index in the power business is strictly required. For the public network, its performance is easily affected by topography, climate, same frequency interference and other uncontrollable factors. Therefore, the reliability is difficult to guarantee[4].

From the below table, the bit error rate of the newest TDLTE technology is less than 10E-5. Meanwhile, telecom grade standard is generally used in the mainstream equipment so as to improve the reliability performance greatly.
TABLE II. COMPARISON OF RELIABILITY FOR THE DIFFERENT WIRELESS TECHNOLOGIES

\begin{tabular}{|c|c|c|c|c|c|}
\hline $\begin{array}{c}\text { Wireless } \\
\text { technolog } \\
\mathrm{y}\end{array}$ & $\begin{array}{c}\text { TD-LTE } \\
230\end{array}$ & $\begin{array}{c}\text { TD-LTE } \\
1800\end{array}$ & McWill & GPRS & CDMA \\
\hline $\begin{array}{l}\text { Equipmen } \\
\mathrm{t} \\
\text { reliability }\end{array}$ & $\begin{array}{l}\text { Industrial } \\
\text { standard }\end{array}$ & $\begin{array}{l}\text { Industrial } \\
\text { standard }\end{array}$ & $\begin{array}{c}\text { Industria } \\
1 \\
\text { standard }\end{array}$ & $\begin{array}{c}\text { Basically } \\
\text { satisfying } \\
\text { industrial } \\
\text { standard }\end{array}$ & $\begin{array}{c}\text { Basical } \\
\text { ly } \\
\text { satisfyi } \\
\text { ng } \\
\text { industr } \\
\text { ial } \\
\text { standar } \\
\text { d } \\
\end{array}$ \\
\hline $\begin{array}{l}\text { Network } \\
\text { reliability }\end{array}$ & Higher & Higher & High & lower & lower \\
\hline $\begin{array}{l}\text { Channel } \\
\text { reliability }\end{array}$ & $\begin{array}{l}\text { Bellow } \\
10 E^{-5}\end{array}$ & $\begin{array}{c}\text { Bellow } \\
10 \mathrm{E}^{-5}\end{array}$ & - & $\begin{array}{c}\text { Bellow } \\
10 \mathrm{E}^{-3}\end{array}$ & $\begin{array}{c}\text { Bellow } \\
10 \mathrm{E}^{-3}\end{array}$ \\
\hline
\end{tabular}

C. Security

From the below table, in the wireless access technologies, TD-LTE, achieving the protection of the main station and terminal, is better than MaWill, GPRS and CDMA in security performance.

TABLE III. COMPARISON OF SECURITY FOR THE DIFFERENT WIRELESS TECHNOLOGIES

\begin{tabular}{|c|c|c|c|c|c|}
\hline $\begin{array}{c}\text { Wireles } \\
\text { s } \\
\text { technol } \\
\text { ogy }\end{array}$ & $\begin{array}{c}\text { TD-LTE } \\
230\end{array}$ & $\begin{array}{c}\text { TD-LTE } \\
1800\end{array}$ & McWill & GPRS & CDMA \\
\hline $\begin{array}{c}\text { Channe } \\
\text { l } \\
\text { security }\end{array}$ & Higher & Higher & High & Lower & Lower \\
\hline $\begin{array}{c}\text { Securit } \\
\text { y } \\
\text { protecti } \\
\text { on } \\
\text { mode }\end{array}$ & $\begin{array}{c}\text { Bidirection } \\
\text { encryption }\end{array}$ & $\begin{array}{c}\text { Bidirecti } \\
\text { onal } \\
\text { encryptio } \\
\text { n }\end{array}$ & $\begin{array}{c}\text { Unidirecti } \\
\text { onal } \\
\text { encryption }\end{array}$ & $\begin{array}{c}\text { Unidirec } \\
\text { tional } \\
\text { encrypti } \\
\text { on }\end{array}$ & $\begin{array}{c}\text { Unidire } \\
\text { ctional } \\
\text { encrypti } \\
\text { on }\end{array}$ \\
\hline $\begin{array}{c}\text { Secret } \\
\text { key } \\
\text { strength }\end{array}$ & AES, ZUC, & AES, & Unpublish & A3, A8, \\
ed & ZUC, & $\begin{array}{c}\text { CAVA, } \\
\text { CMEA, } \\
\text { ORYX }\end{array}$ \\
& & SNOW & $3 G$ & & \\
\hline
\end{tabular}

\section{Transmission Rate}

From the below table, the rate of TD-LTE $1.8 \mathrm{GHz}$ is much higher than GPRS and CDMA. 
TABLE IV. COMPARISON OF TRANSMISSION RATE FOR THE DIFFERENT WIRELESS TECHNOLOGIES

\begin{tabular}{|c|c|c|c|c|c|}
\hline $\begin{array}{l}\text { Wirel } \\
\text { ess } \\
\text { techn } \\
\text { ology }\end{array}$ & $\begin{array}{c}\text { TD-LTE } \\
230\end{array}$ & $\begin{array}{c}\text { TD-LTE } \\
1800\end{array}$ & McWill & GPRS & CDMA \\
\hline $\begin{array}{c}\text { Trans } \\
\text { missi } \\
\text { on } \\
\text { rate }\end{array}$ & $\begin{array}{l}1.76 \mathrm{Mbit} / \mathrm{s} \\
\text { of uplink } \\
\text { peak rate } \\
\text { and } \\
0.5 \mathrm{Mbit} / \mathrm{s} \\
\text { of } \\
\text { download } \\
\text { peak rate in } \\
1 \mathrm{M} \\
\text { frequency } \\
\text { band }\end{array}$ & $\begin{array}{l}\text { 5Mbit/s } \\
\text { of uplink } \\
\text { peak rate } \\
\text { and } \\
26 \mathrm{Mbit} / \mathrm{s} \\
\text { of } \\
\text { downloa } \\
\text { d peak } \\
\text { rate in } \\
5 \mathrm{M} \\
\text { frequenc } \\
\text { y band }\end{array}$ & $\begin{array}{l}\text { 5Mbit/s of } \\
\text { uplink } \\
\text { peak rate } \\
\text { and } \\
\text { 15Mbit/s } \\
\text { of } \\
\text { download } \\
\text { peak rate } \\
\text { in 5M } \\
\text { frequency } \\
\text { band }\end{array}$ & $\begin{array}{c}\text { Generall } \\
\text { y about } \\
\text { 100Kbit/ } \\
\text { s }\end{array}$ & $\begin{array}{l}\text { Generally } \\
\text { about } \\
200- \\
\text { 300Kbit/s }\end{array}$ \\
\hline
\end{tabular}

\section{E. Covering Capacity}

According to the radio frequency characteristics, the lower the frequency band, the wider the covering capacity. Therefore, TD-LTE 1.8GHz technology needs more base stations[5].

TABLE V. COMPARISON OF COVERING CAPACITY FOR THE DIFFERENT WIRELESS TECHNOLOGIES

\begin{tabular}{|c|c|c|c|c|c|}
\hline $\begin{array}{c}\text { Wireless } \\
\text { technolo } \\
\text { gy }\end{array}$ & $\begin{array}{c}\text { TD-LTE } \\
230\end{array}$ & $\begin{array}{c}\text { TD-LTE } \\
1800\end{array}$ & McWill & GPRS & CDMA \\
\hline $\begin{array}{c}\text { Network } \\
\text { mode }\end{array}$ & Flexible & Flexible & Flexible & Flexible & Flexible \\
\hline $\begin{array}{c}\text { Covering } \\
\text { capacity }\end{array}$ & $\begin{array}{c}\text { Below } \\
\text { 3km in the } \\
\text { city proper } \\
\text { and below } \\
\text { 20km in } \\
\text { the } \\
\text { suburbs }\end{array}$ & $\begin{array}{c}\text { Below } \\
1 \mathrm{~km} \text { in } \\
\text { the city } \\
\text { proper } \\
\text { and } \\
\text { below } \\
\text { 5km in } \\
\text { the } \\
\text { suburbs }\end{array}$ & $\begin{array}{c}\text { Below } \\
1 \mathrm{~km} \text { in } \\
\text { the city } \\
\text { proper } \\
\text { and below } \\
\text { 5km in } \\
\text { the } \\
\text { suburbs }\end{array}$ & $\begin{array}{c}\text { Dependi } \\
\text { ng on } \\
\text { the } \\
\text { public } \\
\text { network } \\
\text { capacity }\end{array}$ & $\begin{array}{c}\text { Dependi } \\
\text { ng on } \\
\text { the } \\
\text { public } \\
\text { network } \\
\text { capacity }\end{array}$ \\
& \multicolumn{4}{|c|}{} & \\
\hline
\end{tabular}

\section{CONSTRUCTION SCHEME OF THE POWER WIRELESS PRIVATE NETWORK SYSTEM}

There is about 533 wireless alternative base stations in the power wireless private network of Shanxi province, shown in the following figure.

TABLE VI. ALTERNATIVE NUMBER OF BASE STATION OF SHANXI PROVINVE

\begin{tabular}{|c|c|c|}
\hline Number & City & Alternative number of base station \\
\hline 1 & Changzhi & 60 \\
\hline 2 & Jincheng & 30 \\
\hline 3 & Shuozhou & 30 \\
\hline 4 & Datong & 45 \\
\hline 5 & Jinzhong & 55 \\
\hline 6 & Linfen & 65 \\
\hline 7 & Lvliang & 25 \\
\hline 8 & Taiyuan & 64 \\
\hline 9 & Xinzhou & 73 \\
\hline 10 & Yangquan & 20 \\
\hline 11 & Yuncheng & 66 \\
\hline \multicolumn{2}{|c|}{ In total } & 533 \\
\hline
\end{tabular}

In this project, the wireless core network EPC will be deployed separately in each of 11 cities of Shanxi province, collecting the wireless base station information. Meanwhile, one core switch and network management system is deployed in the dispatching building of Shanxi power company in order to manage the whole network operation better. Moreover, each OMC client will also be used in 11 cities and other part country companies for daily operation and maintenance.

\section{CONCLUSION}

In present, the foundation of the access network is relatively weak compared to the backbone network, and most of power businesses rely on the public network for data transmission. However, data security, reliability and real time can not be guaranteed by transmission in the public network. According to the characteristics of the electric power business transmission, the research of a new type of TD-LTE wireless private communication technology will greatly facilitate the development of power communication networks.

\section{ACKNOWLEDGMENT}

This paper is supported by the project of Life-cycel Asset Management(Project code: 520500170007, Jin Dian Fazhan, No.142, 2018).

\section{REFERENCES}

[1] W.W. Li, B.R. Chen, Q. Wu et al. Applied research of TD-LTE power wireless broadband private network[J]. Communications for Electric Power System, 2012, vol.33,no.241,pp.82-87.

[2] H. Lu, Introduction on modern communications technology in smart grid[J]. Guangdong Power Transmission Technology, 2010, vol.12, no.4, pp.10-13.

[3] F.Z. Gu, McWiLL and its applications in power communication system[J]. Telecommunications for Electric Power System, 2009, vol.30, no.11, pp.424-446.

[4] C.F. Xu, X.B. Wang, C. Zhou et al. Application research of the LTE electric power wireless communication private network for emergency communication[J]. Electric Power Information and Communication Technology, 2015, vol.13,no.1, pp.27-31.

[5] Z.F. Yu, Research on Construction of power wireless communication private network in Hainan[J], Electric Power Information and Communication Technology, 2014, vol.12, no.3, pp.35-40. 